\title{
IMPROVED LATTICE BOLTZMANN METHOD FOR 2D FLOWS IN CURVILINEAR COORDINATES
}

\author{
Ljubomir Budinski ${ }^{1}$ \\ Đula Fabian $^{2}$ \\ Borislav Mašić ${ }^{3}$ \\ Goran Jeftenić ${ }^{4}$ \\ Slobodan Kolaković 5
}

УДК: 532.54

DOI:10.14415/konferencijaGFS 2015.070

Summary: Numerous methods and procedures have preceded successful modeling of flow in physical domains of complex geometry by the lattice Boltzmann method (LBM). Common to these methods is partial deviation from the basic structure of the LBM, resulting in deterioration of accuracy, stability, simplicity and ease of application. In order to minimize the drawbacks as much as possible, a form of LBM based on the principles of the classical CFD with complete transformation of the $2 D$ equations of flow in curvilinear coordinates is proposed in. Suitable forms of the local equilibrium distribution function and of the force term have been developed for the corresponding set of equations, which has been solved by the standard LBM using the original form of the boundary conditions. In order to eliminate the drawbacks of this approach coming from the use of finite difference method in modeling some of the terms, an improved method is outlined as follows. The transformed set of equations of $2 D$ flow - including the Navier-Stokes equations and the shallow water equations - is introduced in a form in which all terms are compatible with the basic structure of the LBM. This results in higher accuracy, while the simple structure of the method and its efficiency is maintained. The benefits of the proposed approach are demonstrated by three test examples. The results of the proposed method are compared with the analytical solution, with results obtained by a laboratory model and with the results of other numerical methods.

Keywords: Curvilinear coordinates, lattice Boltzmann method, Navier-Stokes equations, shallow water equations

\footnotetext{
${ }^{1}$ Dr Ljubomir Budinski, dipl.inž. građ., University of Novi Sad, Faculty of Technical Sciences, Trg Dositeja Obradovica 6, Novi Sad, Serbia, tel: ++381658083688,e-mail: ljubabu@gmail.com

${ }^{2}$ Dr Fabian Đula, dipl.inž. građ., University of Novi Sad, Faculty of Civil Engineering Subotica, Kozaračka 2a, Subotica, Serbia, tel: ++38124554300,e-mail: julius@gf.uns.ac.rs

${ }^{3} \mathrm{MsC}$ Borislav Masic, dipl.inž.građ., University of Novi Sad, Faculty of Technical Sciences, Trg Dositeja Obradovica 6, Novi Sad, Serbia, tel: ++381611883068,e-mail: boramasic@gmail.com

${ }^{4} \mathrm{MsC}$ Goran Jeftenić, dipl.inž.građ., University of Novi Sad, Faculty of Technical Sciences, Trg Dositeja Obradovica 6, Novi Sad, Serbia, tel: ++381642854098,e-mail: goran.jeftenic@yahoo.com

${ }^{5} \mathrm{MsC}$ Slobodan Kolaković, dipl.inž.građ., University of Novi Sad, Faculty of Technical Sciences, Trg Dositeja Obradovica 6, Novi Sad, Serbia, tel: ++381631028562,e-mail: cole86grb@gmail.com
} 


\section{INTRODUCTION}

The advantageous features of the lattice Boltzmann method (LBM) are reflected in the ease of implementation of a wide range of flow related physical processes including transport of suspended and dissolved substances, multiphase flow and so on. In addition, performance improving applications (like parallel processing) can be easily combined with the method, providing high computation efficiency. These are the practical reasons for why the LBM has become the tool of choice for an increasing number of researchers. Furthermore, the problems associated with classical numerical methods (finite difference method, finite volume method) are significantly reduced or even completely eliminated by the LBM. These include difficulties in modeling of advection, dealing with complexshape flow domains and application of boundary conditions to the curved boundaries. However, with the application of the LBM to a continuously expanding range of flow related problems (river hydraulics, chemical industry) a need for adjustments in order to increase the capacity of the method has emerged.

It has been recognized that the method of application of the boundary conditions plays a key role in producing an accurate and stable final solution, for that significant effort has been invested in the LBM to make it more suitable for modeling flow domains with difficult boundaries. In this respect there are two distinctive groups of the LBM. The first group includes procedures which solve complex flow domains by means of non-uniform calculation meshes. Using the experience gained by the classical CFD, a group of authors $[1,2,3]$ has developed a method based on solving the partial differential lattice Boltzmann equations transformed into a curvilinear coordinate system using classical numerical procedures. The obvious drawback of this approach is in getting farther from the essential principals of the LBM while introducing the well-known problems associated with the procedures of the classical CFD. The procedures of the second group utilize a uniform calculation mesh. In this case the expressions describing the boundary conditions need to be corrected whenever the direction of the boundary segment does not comply with the direction of the calculation axis. Filippova and Hänel [11] have proposed a method for the calculation of the unknown distribution functions, subsequently modified and improved by $[5,6]$. All of the listed methods have a negative effect on the essential characteristics of the LBM in regards to efficiency, accuracy and stability. In order to get rid of the listed drawbacks, an improved LBM is proposed here for modeling flows in physical domains of complex geometry. A revised transformation compared to that one described in [7] and writing the free terms as proposed in [8] have reduced the force term, increased the efficiency of the method and improved the accuracy of the final solution. 
Међународна конференција

Савремена достигнућа у грађевинарству 24. април 2015. Суботица, СРБИЈА

\section{THE MATHEMATICAL MODEL}

\subsection{Complete transformation of the 2D Navier-Stokes equations in a curvilinear coordinate system}

The system of 2D Navier-Stokes equations as well as the shallow water equations describing flow in the physical domain in Cartesian coordinates can be transformed into a curvilinear coordinate system of the computational domain in two ways. The first approach is based on partial transformations between the physical and the computational domain. By transforming the independent variables only, the metrics between the physical and the computational domain become established, while the Cartesian components of the dependent variables are maintained. Another approach, the method of complete transformation, has been adapted for the LBM proposed in this work [9]. Both the independent and the dependent variables are transformed.

\subsection{Application of the Lattice Boltzmann method on the system of equations transformed into a $2 \mathrm{D}$ curvilinear coordinate system}

The concept of the LBM is based on modeling of the evolution of the distribution function of particles, using the Boltzmann equation of the discrete phase-space system. Defined over a square lattice domain (Fig. 1), the discretized Boltzmann equation is written as:

$$
f_{\alpha}\left(\varsigma+e_{\alpha} \Delta t, t+\Delta t\right)=f_{\alpha}(\varsigma, t)-\frac{1}{\tau}\left(f_{\alpha}-f_{\alpha}^{e q}\right)+F_{\alpha} \Delta t+Z_{\alpha},
$$

where $e=\Delta \xi / \Delta t=\Delta \eta / \Delta t$ are the components of velocity $e_{\alpha}$ in $\xi$ and $\eta$ directions (Fig. 1), defined in a D2Q9 model as:

$$
e_{\alpha}=\left[\begin{array}{ll}
(0,0), & \alpha=0 \\
( \pm e, 0), & \alpha=1,5 \\
(0, \pm e), & \alpha=3,7 \\
( \pm e, \pm e), & \alpha=2,4,6,8 .
\end{array}\right.
$$

In equations (1) and (2) $\Delta \xi$ and $\Delta \eta$ are lattice sizes in $\xi$ and $\eta$ directions (in case of a square lattice $\Delta \xi=\Delta \eta), f_{\alpha}$ is the distribution function of particles at the $\alpha$ link, $f_{\alpha}^{e q}$ is the local equilibrium distribution function, $\zeta$ is the location vector in the $2 \mathrm{D}$ curvilinear domain defined as $\zeta=(\xi, \eta), t$ is time and $\Delta t$ is the time step. $F_{\alpha}$ is defined as force, while $Z_{\alpha}$ is an additional element in modeling free terms of the LBM [8]. 


\section{$41^{\text {th }}$ ANNIVERSARY FACULTY OF CIVIL ENGINEERING SUBOTICA}

International conference

Contemporary achievements in civil engineering 24. April 2015. Subotica, SERBIA

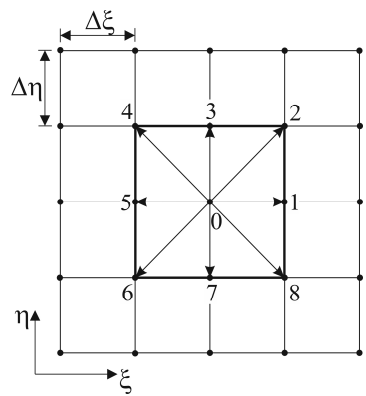

Figure 1. The calculation domain of the LBM in case of the D2Q9 square lattice model

\subsection{The completely transformed 2D Navier-Stokes equations}

In order to accommodate the LBM for modeling domains of complex shape utilizing the system of equations transformed into a curvilinear coordinate system, the local equilibrium distribution function needs to be defined initially. Based on the form of the equilibrium function given in [4], the first-hand version of the local equilibrium distribution function is proposed here for the 2D Navier-Stokes equations completely transformed into a curvilinear coordinate system:

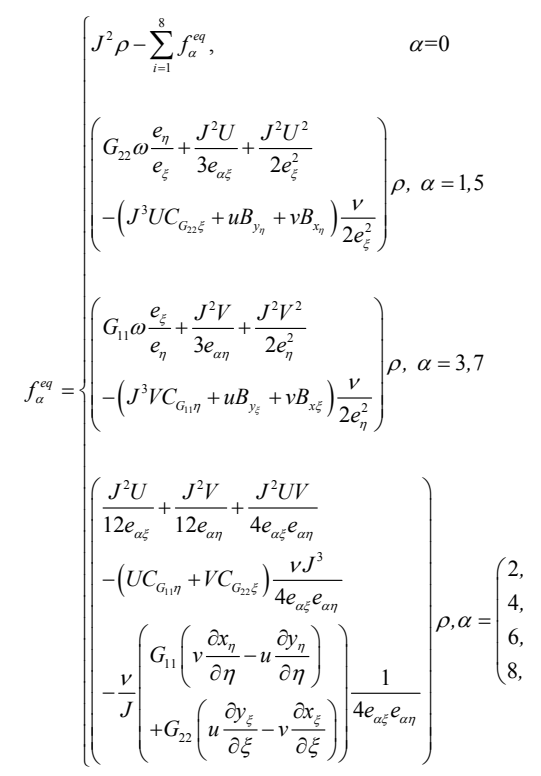

where terms $B_{y_{\eta}}, B_{x_{\eta}}, B_{y_{\xi}}, B_{x_{\xi}}, C_{G_{22} \xi}, C_{G_{22} \eta}, C_{G_{I I} \xi}$ and $C_{G_{1} \eta}$ are exclusively the product of geometrical transformations between the physical and the computational domain, using the finite difference method: 
Међународна конференција

Савремена достигнућа у грађевинарству 24. април 2015. Суботица, СРБИЈА

$$
\begin{aligned}
& B_{y_{\eta}}=\frac{1}{J}\left(G_{12} \frac{\partial y_{\eta}}{\partial \eta}-G_{22} \frac{\partial y_{\eta}}{\partial \xi}\right), B_{x_{\eta}}=\frac{1}{J}\left(G_{22} \frac{\partial x_{\eta}}{\partial \xi}-G_{12} \frac{\partial x_{\eta}}{\partial \eta}\right), C_{G_{22} \xi}=\frac{\partial}{\partial \xi}\left(\frac{G_{22}}{J^{3}}\right), C_{G_{22} \eta}=\frac{\partial}{\partial \eta}\left(\frac{G_{22}}{J^{3}}\right), \\
& B_{y_{\xi}}=\frac{1}{J}\left(G_{11} \frac{\partial y_{\xi}}{\partial \eta}-G_{12} \frac{\partial y_{\xi}}{\partial \xi}\right), B_{x_{\xi}}=\frac{1}{J}\left(G_{12} \frac{\partial x_{\xi}}{\partial \xi}-G_{11} \frac{\partial x_{\xi}}{\partial \eta}\right), C_{G_{11} \xi}=\frac{\partial}{\partial \xi}\left(\frac{G_{11}}{J^{3}}\right), C_{G_{11} \eta}=\frac{\partial}{\partial \eta}\left(\frac{G_{11}}{J^{3}}\right) .
\end{aligned}
$$

Force term $F_{\alpha}$ comprises the leftover of advection, $S_{x}$ and $S_{y}$, as well as terms on the right hand side of the continuity equation. Terms $E_{\xi}$ and $E_{\eta}$ are defined as:

$$
\begin{aligned}
& E_{\xi}=J \rho\left(u\left(\frac{\partial y_{\xi}}{\partial \eta} U+\frac{\partial y_{\eta}}{\partial \eta} V\right)-v\left(\frac{\partial x_{\xi}}{\partial \eta} U+\frac{\partial x_{\eta}}{\partial \eta} V\right)\right)+J y_{\eta} S_{x}-J x_{\eta} S_{y}, \\
& E_{\eta}=J \rho\left(-u\left(\frac{\partial y_{\xi}}{\partial \xi} U+\frac{\partial y_{\eta}}{\partial \xi} V\right)+v\left(\frac{\partial x_{\xi}}{\partial \xi} U+\frac{\partial x_{\eta}}{\partial \xi} V\right)\right)-J y_{\xi} S_{x}+J x_{\xi} S_{y},
\end{aligned}
$$

while force $F_{\alpha}$ is

$$
F_{\alpha}= \begin{cases}0, & \alpha=0 \\
\frac{E_{\xi}}{6 e_{\alpha \xi}}+\frac{J \rho U}{6} \frac{\partial J}{\partial \xi}, & \alpha=1,5 \\
\frac{E_{\eta}}{6 e_{\alpha \eta}}+\frac{J \rho V}{6} \frac{\partial J}{\partial \eta}, & \alpha=3,7 \\
\left(\frac{E_{\xi}}{6 e_{\alpha \xi}}+\frac{E_{\eta}}{6 e_{\alpha \eta}}\right)+\left(\frac{J \rho U}{6} \frac{\partial J}{\partial \xi}+\frac{J \rho V}{6} \frac{\partial J}{\partial \eta}\right), \alpha=\left\{\begin{array}{l}
2, \\
4, \\
6, \\
8 .
\end{array}\right.\end{cases}
$$

Force term $F_{\alpha}$ requires special treatment in the LBM. Accordingly, it is modeled here using the semi-implicit form of the centered scheme, which is second-order accurate in space and first-order in time [10]. The last group of terms is modeled as

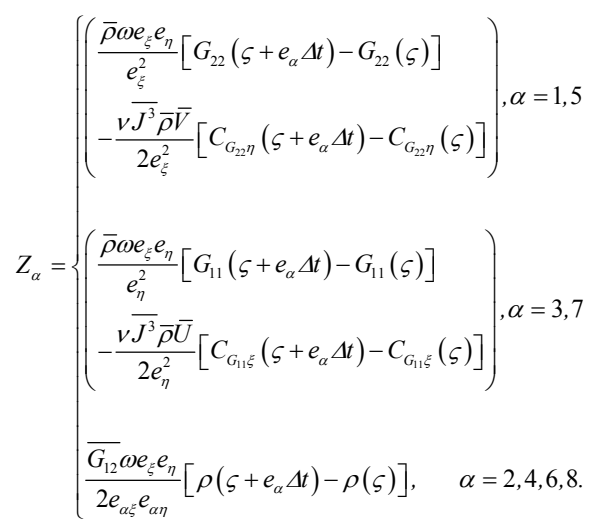




\section{$41^{\text {th }}$ ANNIVERSARY FACULTY OF CIVIL ENGINEERING SUBOTICA}

International conference

Contemporary achievements in civil engineering 24. April 2015. Subotica, SERBIA

Parameter $\omega$ providing stability to equations (3) and (7) is defined by Zhou [4]

$$
\omega<\min \left\{\frac{\Delta \xi}{\Delta \eta}, \frac{\Delta \eta}{\Delta \xi}\right\} \leq 1.0 .
$$

Applying the Chapman-Enskog analysis [24] to expressions:

$$
\rho=\frac{1}{J^{2}} \sum_{\alpha=0}^{8} f_{\alpha}, U=\frac{1}{J^{2} \rho} \sum_{\alpha=0}^{8} e_{\alpha \xi} f_{\alpha}, V=\frac{1}{J^{2} \rho} \sum_{\alpha=0}^{8} e_{\alpha \eta} f_{\alpha},
$$

results in a relationship between pressure and density in the form of $p=2 \rho \omega e_{\xi} e_{\eta}$. The same analysis shows that the proposed model is constrained in terms of relaxation time $\tau$. In case of a square lattice the kinematic viscosity yields:

$$
v=\left(\frac{J^{2}}{G}\right) \frac{e_{\xi} e_{\eta} \Delta t}{6}(2 \tau-1.0),
$$

\section{VALIDATION}

\subsection{Open channel flow in a $180^{\circ}$ bend}

To put the proposed CL-LBM to rigorous verification, a complex example has been chosen next; the Taylor-Couette flow between two cylinders (Fig. 2). The inner cylinder of radius $R_{1}$ rotates, while the outer cylinder of radius $R_{2}=0.4 \mathrm{~m}$ is kept motionless. The configuration of the experimental rig as well as the physical flow domain is defined by ratio $\beta=R_{1} / R_{2}$. Three different cases with $\beta_{1}=0.35, \beta_{2}=0.5$ and $\beta_{3}=0.65$ have been considered. 


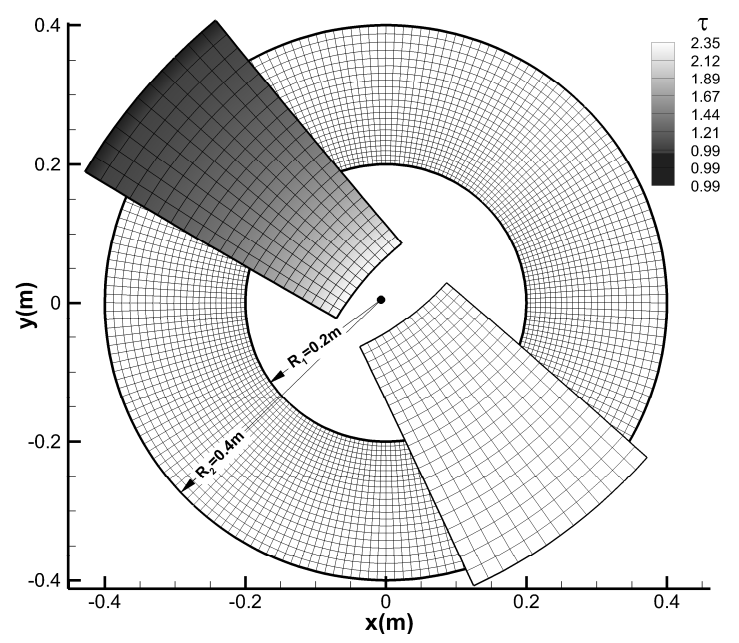

Fig. 2. Dimensions of the test rig with the details of the calculation mesh and the corresponding range of the relaxation time $\tau$ for $\beta=0.5$

Exploiting boundary conditions developed for the impervious boundaries, tangential velocity of clockwise rotation $W_{R_{1}}^{t}=0.176 \mathrm{~m} / \mathrm{s}$ has been applied to the inner cylinder, while the outer cylinder has been kept stationary, $W_{R_{2}}^{t}=0.0 \mathrm{~m} / \mathrm{s}$. In case of the permeable boundaries, like in the first test example, periodical boundary conditions have been applied. In the first set of numerical experiments $\beta$ has taken three different values while the Reynolds number defined as $R e=\left(R_{2}-R_{1}\right) W_{R_{1}}^{t} / v$ has been kept constant. The adopted value of $R e=7.0$ for the assumed values of $\beta_{1}=0.35, \beta_{2}=0.5$ and $\beta_{3}=0.65$ supplied viscosity coefficients $v_{1}=0.0065 \mathrm{~m}^{2} / \mathrm{s}, \quad v_{2}=0.0050 \mathrm{~m}^{2} / \mathrm{s}$ and $v_{3}=0.0035 \mathrm{~m}^{2} / \mathrm{s}$, respectively. Fig. 3 shows that for $\beta=0.5$ and the corresponding kinematic viscosity $\nu=0.005 \mathrm{~m}^{2} / \mathrm{s}$, relaxation time $\tau$ is ranging from $\tau=2.35$ by the inner cylinder, up to $\tau=0.99$ along the outer boundary. 


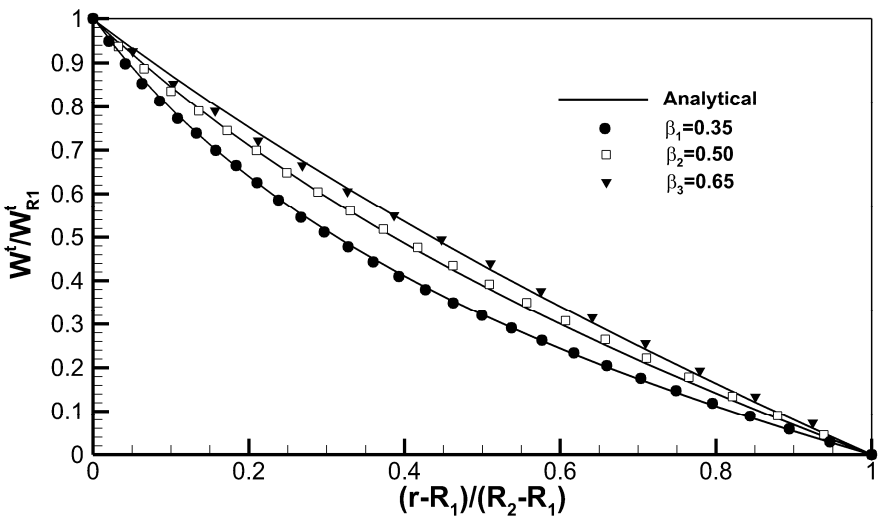

Fig. 3. Comparison of results produced by the CL-LBM to the analytical solution in the form of normalized tangential velocities in case of the rotating inner cylinder

The quantification of the discrepancy between the numerical and analytical results is given in Table 1.

Table 1 Computational errors for different values of $\beta$

\begin{tabular}{llll}
\hline \hline & $L^{\infty}$ & $L^{1}$ & $L^{2}$ \\
\hline$\beta_{1}$ & 0.011 & 0.008 & 0.008 \\
$\beta_{2}$ & 0.013 & 0.011 & 0.012 \\
$\beta_{3}$ & 0.016 & 0.015 & 0.014 \\
\hline
\end{tabular}

Additional verification of the proposed model has been implemented for the configuration defined by $\beta=0.5$, by variation of the viscosity coefficient or rather the Reynolds number. The aim of this analysis is to quantify the influence of the Reynolds number on the accuracy and stability of the numerical model. It is feasible since the relative velocity distribution is not dependant on the shear stresses induced. For three different Reynolds numbers $R e_{1}=7.03\left(v_{1}=0.0050 \mathrm{~m}^{2} / \mathrm{s}\right), R e_{2}=17.60\left(v_{2}=0.0020 \mathrm{~m}^{2} / \mathrm{s}\right)$ and $\operatorname{Re}_{3}=29.30\left(v_{3}=0.0012 \mathrm{~m}^{2} / \mathrm{s}\right)$ the corresponding velocity error norms between the numerical and analytical solution have been calculated and summarized in Table 2.

Table 2 Error norms in function of the Re number for $\beta=0.5$

\begin{tabular}{llll}
\hline \hline & $L^{\infty}$ & $L^{1}$ & $L^{2}$ \\
\hline$R e_{1}$ & 0.013 & 0.011 & 0.012 \\
$R e_{2}$ & 0.021 & 0.016 & 0.017 \\
$R e_{3}$ & 0.022 & 0.019 & 0.021 \\
\hline \hline
\end{tabular}

\section{CONCLUSIONS}

In order to produce a LBM which maintains the basic characteristics of the original method without jeopardizing accuracy, and supports modeling of flow in domains of

\section{2}


Међународна конференција

Савремена достигнућа у грађевинарству 24. април 2015. Суботица, СРБИЈА

complex geometry, a new form of the LBM is proposed for solving the flow equations completely transformed into a curvilinear coordinate system. In accordance with the structure and character of the LBM, an appropriate form of the local equilibrium distribution function $f_{\alpha}$, force term $F_{\alpha}$ and additional term $Z_{\alpha}$ has been produced for the system of transformed Navier-Stokes equations and for the shallow water equations as well. Using the principals of the classical CFD for modeling flow in complex-shape domains (river hydraulics) which means that the physical domain of interest is covered by a curvilinear mesh completely adapted to the given geometry, this approach provides opportunity for applying boundary conditions in a simple, straightforward way. The simplicity of the basic form of the LBM in terms of the corresponding algebraic expressions is maintained. This has eliminated the difficulties in cumbersome application of the boundary conditions, along with the related errors. Furthermore, parallel processing is enabled by the proposed approach. The discrepancy of the proposed procedure from the results obtained by three other numerical methods and by measurements is quantified.

\section{ACKNOWLEDGEMENTS}

This work is supported by research within project "Development and application of contemporary procedures for design, construction and maintenance of buildings", Faculty of Technical Sciences-Department of Civil Engineering, University of Novi Sad, Republic of Serbia.

\section{REFERENCES}

[1] R.W. Mei, W. Shyy, On the Finite Difference-Based Boltzmann Method in Curvilinear Coordinates, Journal of Computational Physics 143, 1998, 426-448.

[2] Z. Guo, T.S. Zhao, Explicit finite-difference lattice method for curvilinear coordinates, Physical Review E 67, 2003, 1-12.

[3] G. Peng, H. Xi, C. Duncan, S.H. Chou, Lattice Boltzmann method on irregular meshes, Physical Review E 58, 1998, 4124-4127.

[4] J.G. Zhou, Rectangular lattice Boltzmann method, Physical Review E 81, 2010, 1 10 .

[5] R. Mei, L.S. Luo, W. Shyy, An Accurate Curved Boundary Treatment in the Lattice Boltzmann Method, Journal of Computational Physics 155, 1999, 307-315.

[6] Z. Guo, C. Zheng, B. Shi, An extrapolation method for boundary conditions in lattice Boltzmann method, Physics of Fluids 14, 2002, 2007-2010.

[7] Lj. Budinski, Lattice Boltzmann method for 2D flows in curvilinear coordinates, Journal of Hydroinformatics 14 (3), 2012, 772-783.

[8] J.G. Zhou, Enhancement of the LABSWE for Shallow Water Flows, Journal of Computational Physics 230 (2), 2011, 394-401.

[9] J.G. Simmonds, A Brief on Tensor Analysis, Springer, New York, 1994.

[10] J.G. Zhou, Lattice Boltzmann Methods for Shallow Water Flows, Springer-Verlag, Berlin, 2004. 
[11] O. Filippova, D. Hänel, Grid Refinement for Lattice-BGK Models, Journal of Computational Physics 147 (1998) 219-228.

\section{POBOLJŠANA METODA LATTICE-BOLTZMANN ZA PRORAČUN 2D PROTOKA U KRIVOLINIJSKIM KOORDINATAMA}

Rezime: Veliki broj metoda je prethodio uspešnom modeliranju protoka u fizičkim domenima složene geometrije metode Lattice-Boltzmann-a (LBM). Zajednička osobina svih ovih metoda je parcijalni izvod osnovne strukture metode Lattice-Boltzmann-a, što rezultuje pogoršanjem tačnosti $i$ stabilnosti, kao i jednostavnosti primene. U cilju minimiziranja nedostataka što je više moguće, predložena je forma LBM zasnovana na principima klasične CFD, sa kompletnom transformacijom dvodimenzionalnih jednačina protoka u krivolinijske koordinate. U cilju eliminisanja nedostataka ovog pristupa, koje dolaze usled upotrebe metode konačnih razlika u modeliranju određenih uslova, poboljšana metoda je koncipirana na sledeći način: transformisani set jednačina za proračun $2 D$ protoka, uključujući Navie-Stokesove jednačine i Sen-Venanove jednačine osrednjene po dubini, su predstavljene u formi takvoj da su svi uslovi kompatibilni sa osnovnom strukturom LBM. Ovi rezultati imaju veću tačnost, uz očuvanje jednostavnosti strukture i efikasnosti same metode. Prednost predloženog pristupa demonstrirana je kroz tri brojna primera. Rezultati predložene metode su upoređeni sa analitičkim rešenjem, rešenjem dobijenim na laboratorijskom modelu i sa rezultatima drugih numeričkih metoda.

Ključne reči: Krivolinijske koordinate, metoda Lattice-Boltzmann, Navi-Stokesove jednačine, Sen-Venanove jednačine osrednjene po dubini 